\title{
ARTYKUtY
}

Klio. Czasopismo poświęcone dziejom Polski i powszechnym

PL ISSN 1643-8191, t. 57 (1)/2021, s. 89-111

(c) $(1)$

http://dx.doi.org/10.12775/KLIO.2021.004

JOANNA ORZEe ${ }^{*}$

\section{Wspólnota, religia, prawa - mit o trojańskim pochodzeniu w angielskiej historiografii przedoświeceniowej ${ }^{* *}$}

\section{Community, religion, laws - the myth of Trojan origin in English pre-Enlightenment historiography}

Streszczenie: W średniowieczu większość państw Europy Zachodniej poszukiwała swoich korzeni w wojnie trojańskiej. Jednym z nich była Anglia. W XII w. Geoffrey z Monmouth stworzył opowieść, w której założycielem państwa uczynił Brutusa spod Troi. Na kilka wieków stała się ona podstawą do dyskusji między pisarzami na temat początków państwa. Opowieść ta była również wykorzystywana przez kolejnych monarchów - w propagandzie wojennej, dla podkreślenia niezależności od papieża lub w celu wzmocnienia władzy królewskiej. Choć opowieść o trojańskim pochodzeniu została wcześnie skrytykowana, niektórzy pisarze nie chcieli odrzucić wielowiekowej tradycji.

* Instytut Historii Uniwersytetu Łódzkiego, ul. Prezydenta Gabriela Narutowicza 68, 90-136 Łódź, joanna.orzel@uni.lodz.pl / joanna.orzel@interia.eu, ORCID: 0000-0001$-8816-5157$.

** Artykuł jest wynikiem badań przeprowadzonych dzięki stypendium Fundacji z Brzezia Lanckorońskich. 
Abstract: In the Middle Ages, most Western European countries searched for their roots in the Trojan War. One of them was England. In the $12^{\text {th }}$ century, Geoffrey of Monmouth created a story in which he made Brutus of Troy the founder of the state. For several centuries, the story became the basis for discussion among writers about the origins of the state. The story was also used by successive monarchs - in war propaganda, to emphasize independence from the Pope or to strengthen royal power. Although the Trojan origin story was criticized early on, some writers did not want to reject the centuries-old tradition.

Słowa kluczowe: pamięć kulturowa, mit pochodzenia, wojna trojańska, historiografia angielska, historia wczesnonowożytna

Keywords: cultural memory, myth of origin, Trojan War, English historiography, early modern period

$\mathrm{P}$ amięć kulturowa opiera się na tekstach kultury kształtujących tożsamość grupy, która się z nimi identyfikuje, zyskując w ten sposób i utrwalając swoją tożsamość ${ }^{1}$. Opisane w nich najdawniejsze dzieje państwa, czyli najczęściej opowieści fundacyjne, są mocno skonkretyzowane - określone przestrzennie i czasowo, wypełnione postaciami, z których najważniejszą funkcję pełnią ojcowie założyciele konkretnych krajów czy społeczności. Hugh Trevor-Roper zwrócił uwagę, że niektóre narody są bardziej mitopeiczne, można by powiedzieć: mitotwórcze, aniżeli inne. Największe znaczenie elementów mitycznych w rozwoju społeczności miały według niego mity greckie, tak mocno złączone z grecką historią i literaturą. Na przeciwległym biegunie znajdują się Anglosasi, ponieważ żadna opowieść z ich narodowej mitologii nie pochodzi z kultury anglosaskiej ${ }^{2}$. Do XIX stulecia istniały dwie koncepcje etnogenetyczne społeczeństwa angielskiego: trojańska i anglosaska. Pierwsza z nich pojawiła się w pisarstwie średniowiecznym i wpisywała się w zachodnioeuropejską modę na posiadanie konotacji z Troją. W czasach renesansu coraz częściej krytykowano zbyt fantastycz-

1 A. Assmann, Czym sq teksty kulturowe?, tłum. A. Konarzewska, w: idem, Między historia a pamięcia. Antologia, red. M. Saryusz-Wolska, Warszawa 2013, s. 36.

2 H. Trevor-Roper, The invention of Scotland. Myth and history, New Heaven-London 2008, s. XIX. 
ne początki: tak jak Francuzi prowadzili dyskusję, czy ich przodkami byli Frankowie, czy Gallowie ${ }^{3}$, tak w Anglii w epoce odrodzenia popularność zyskał konkurencyjny wobec trojańskiego mit anglosaskí .

W artykule skupię się na genezie i rozwoju mitu o trojańskim pochodzeniu mieszkańców Wysp Brytyjskich oraz na debacie na temat jego wiarygodności, w tym argumentów, które w epoce nowożytnej (do końca XVII w.) pojawiały się za jego utrzymaniem lub odrzuceniem. Zaprezentowane zostaną także przykłady jego politycznego wykorzystania. Kluczową postacią, wokół której prowadzona będzie narracja, ustanowiłam ojca założyciela „narodu brytyjskiego” - Brutusa. Niejednokrotnie będzie on zestawiany z królem Arturem, który w pewnym momencie i w określonych okolicznościach politycznych stał się drugim fundatorem, a mit trojański przeobraził się w legendę o trojańsko-arturiańskich początkach.

Wpisanie początków państwa w historię powszechną zrównywało mieszkańców Wysp Brytyjskich z innymi zachodnioeuropejskimi narodami jako spadkobierców grecko-rzymskiego antyku. Pierwszą pracą podejmującą interesującą nas tematykę jest Historia Brittonum anonimowego autora (przypisuje się ją walijskiemu mnichowi Nenniuszowi) z pierwszej połowy IX w., choć jest ona znana tylko z odpisów powstałych po XI w. Przeszłość państwowa została tu zespolona z Biblią - pochodzeniem od potomka Noego Jafeta, któremu w podziale ziem przypadła Europa. Kolejnymi przywołanymi w dziele bohaterami byli Eneasz - uciekinier spod Troi, i jego wnuk Brutus (zwany też Brytonem). Osiedlił się on na wyspie, która na jego cześć została nazwana Brytanią.

Największy wpływ na spopularyzowanie mitu o trojańskim pochodzeniu mieszkańców Wysp Brytyjskich miała Historia królów Brytanii walijskiego duchownego Geoffreya z Monmouth z 1138 r. Początki państwa według tego kronikarza również wiążą się z potomkiem Eneasza, Brutusem. Przed jego narodzeniem w Italii czarownik przepowiedział, że rodzice Brutusa zginą z jego powodu. Jego matka zmarła przy porodzie, a po 15 latach

3 Z pokaźnej literatury na ten temat przede wszystkim warto sięgnąć do: C. Beaune, Naissance de la nation, Paris 1985, s. 15-54.

4 Zob. A. Branny, Idea anglosaskiego rodowodu w angielskiej świadomości historycznej XVI-XVII wieku, „Historyka. Studia metodologiczne” 1990, t. 20, s. 33-49. 
przypadkowo śmiertelnie ranił on swego ojca podczas polowania, za co został wygnany z Rzymu. Udał się do Grecji, gdzie znalazł ocalałych z wojny Trojańczyków, przetrzymywanych w niewoli. Brutus został ich przywódcą i po serii zwycięstw nad greckim władcą Pandrasusem wymusił na nim uwolnienie swych towarzyszy. Ponadto pojął za żonę córkę greckiego króla, otrzymał statki oraz aprowizację potrzebną do podróży. W jej trakcie Brutus miał profetyczny sen, w którym widział kraj przeznaczony mu do zasiedlenia, wówczas zaś zamieszkany tylko przez olbrzymów. Żegluga (podczas której spotkał syreny i walczył z Galami) doprowadziła ok. 1170 r. p.n.e. ${ }^{5}$ okręty do Albionu, który stał się dla Brutusa ziemią obiecaną. Tam bohater pokonał olbrzymów, a podbity kraj został nazwany eponimem od jego imienia - Brytanią. Nad brzegiem Tamizy bohater założył miasto i przez wzgląd na swoje pochodzenie nazwał je Troia Nova. Później przekształcono je w Trinovantum (następnie zaś w Londyn) ${ }^{6}$. Nawet Rzym nie był tak określony przez Wergiliusza ${ }^{7}$, co było dodatkowym wywyższeniem zarówno nowego miasta, jak i samego Brutusa. Rządził on przez 20 lat zgodnie ze stanowionym przez siebie prawem. Po jego śmierci Brytania została podzielona między jego synów: Locrinusa (który otrzymał Anglię), Albanactusa (któremu podarowana została Szkocja) i Kambera (dziedziczącego Walię). Po śmierci najmłodszego syna ziemie zostały złączone i znalazły się pod władzą Locrinusa. Następnie Brytanią rządzili kolejni fantastyczni królowie, m.in. Artur czy Lear, aż do pierwszego poświadczonego źródłowo władcy ${ }^{8}$. Tworząc opowieść, Geoffrey z Monmouth zastosował konstrukcję znaną z Iliady, Odysei oraz Eneidy, zawierającą popularne elementy: wojna, wędrówka do nowej krainy, założenie stolicy i nazwanie państwa od swojego imienia. Brutus otrzymał wszystkie atrybuty założyciela9 a Historię

5 T. D. Kendrick, British antiquity, New York-London 1950, s. 7.

6 Geoffrey z Monmouth, Historia królów Brytanii, tłum. A. Radomyska, Sandomierz 2012, s. 8-31.

7 J. Carscallen, How Troy came to Spenser, w: Fantasies of Troy. Classical tales and the social imaginary in medieval and early modern Europe, eds. A. Shepard, S. D. Powell, Toronto 2004, s. 18.

8 Skrótowo władców tych charakteryzuje H. A. MacDougall, Racial myth in English history. Trojans, Teutons, and Anglo-Saxons, Montreal-Hanover-London 1982, s. 9-11.

9 F. Mora, L’Enéide médiévale et la naissance du roman, Paris 1994, s. 67. 
królów Brytanii można traktować jako przykład nowej Eneidy. W XII w. Troja była istotnym składnikiem wielu historii narodowych tworzonych przez zachodnioeuropejskich kronikarzy ${ }^{10}$. Co warte podkreślenia, w dziele Geoffreya z Monmouth bohaterowie fikcyjni są przeplatani postaciami rzeczywistymi, jak chociażby Juliuszem Cezarem, Karakallą, Konstantynem czy Konstancjuszem. Zabieg ten uwiarygodniał przekaz, podobnie jak relacja o „odnalezionym” po latach grobie króla Artura.

Zgodnie z przekazem kronikarza ostatni mityczny król Brytów - Cadwaladr (Cadwallader), usłyszał głos anioła, który przepowiedział mu, że jego dynastia zostanie przywrócona dopiero po kolejnych okresach dominacji Sasów i Normanów. Cadwaladr uznał to za wiadomość od Opatrzności, zrezygnował z korony, wybrał się do Rzymu i poświęcił życiu religijnemu ${ }^{11}$. Zmarł 12 maja 689 r. w Wiecznym Mieście. Jego synom pozostałym w ojczyźnie nie udało się utrzymać niezależności politycznej z powodu najazdu obcych plemion. Do dziedzictwa „brytyjskiego” mogli wówczas odnosić się tylko Walijczycy, a ziemie były coraz częściej zasiedlane przez plemiona saskie. Ich przybycie zostało przedstawione jako kara za grzechy, zgodnie ze średniowieczną historiozofią. Dzieło Geoffreya z Monmouth kończy się zapowiedzią odrodzenia się rodu i odzyskania utraconego królestwa ${ }^{12}$, ponownego zjednoczenia państwa i nacji. Jak słusznie zauważa Andrzej Branny, dzieje narodu to historia dynastii, której każdy władca otrzymuje dziedzictwo przeszłości:

Ta konstrukcja pozwala autorowi schlebić dumie narodowej Walijczyków, o których mówi, że są potomkami dawnych Brytów, jak też wysunąć nęcącą ofertę pod adresem aktualnych władców Anglii. Pozostawiając w mroku tajemnicy ostatnie ogniwa królewskiej linii, Geoffrey stwarza

10 Por. K. Wolff, Troja-Metamorphosen eines Mythos. Französische, englische und italienische Überlieferungen des 12. Jahrhunderts im Vergleich, Berlin 2009, passim; L. Mathey-Maille, Mythe troyen et histoire romaine: de Geoffrey de Monmouth au "Brut " de Wace, w: Entre fiction et histoire: Troie et Rome au Moyen Age, éd. E. Baumgartner, L. Harf-Lancner, Paris 1997, s. 115.

11 Geoffrey z Monmouth, op. cit., s. 266-267.

12 R. Bizzocchi, Genealogie incredibili. Scritti di storia nell'Europa moderna, Bologna 1995, s. 73-74. 
im możliwość dopisania własnych imion do trojańsko-arturiańskiej metryki ${ }^{13}$.

Dzieło średniowiecznego kronikarza służyło zatem jako argument w legitymizacji władzy.

Warto wspomnieć, że mit trojański (zwany też normańsko-walijskim) nie był jedyną legendą o pochodzeniu mieszkańców Wysp Brytyjskich. Konkurencyjny wobec niego był mit szkocki. Według opowieści powstałej w 1249 r. Gaedil Glas (gr. Gaythelos, łac. Gathelus), syn króla ateńskiego, ożenił się ze Scotą, córką egipskiego faraona, który prześladował Izraelitów, za co został ukarany plagami. To jeden z wielu przykładów mitu fundacyjnego łączącego historię grecką ze Starym Testamentem. Dzięki temu zabiegowi Szkocja mogła szczycić się dłuższą historią aniżeli zdecydowana większość europejskich krajów. Gathelus i Scota wraz ze swoimi poddanymi wyruszyli do Hiszpanii, następnie ich potomkowie udali się do Irlandii. W 333 r. p.n.e. odnaleźli ziemię obiecaną, którą na cześć Egipcjanki nazwali Szkocją ${ }^{14}$. Podanie to było popularyzowane przez szkockiego uczonego Hectora Boece'a (Boethiusa) (1465-1536). W wydanej w 1527 r. Historia Gentis Scotorum opisał on historię Szkocji od Scoty do wstąpienia na tron Jakuba I. Uczony wypełnił mityczne szkockie dzieje - na podobieństwo historii przedstawionej przez Geoffreya z Monmouth, którą Boece uznawał za prawdziwą - licznymi władcami, a w jego przekazie pojawił się również król Artur ${ }^{15}$. Z czasem, podobnie jak inne mity założycielskie, także i ta historia została uznana za bajkę.

Wracając do postaci Brutusa spod Troi, należy podkreślić, że wątpliwości wobec mitycznego przekazu pojawiły się bardzo wcześnie, bo już w XII stuleciu, czyli w tym samym, w którym dzieło Geoffreya z Monmouth się ukazało. William z Newburgh (1136-ok. 1198) w Historia Rerum Anglicarum (1196-1198), opisującej historię Anglii od 1066 do 1198 r., uznał,

13 A. Branny, Trojanie i król Artur w angielskiej świadomości historycznej do XVIII wieku, „Historyka. Studia metodologiczne” 1986, t. 16, s. 6.

${ }_{14}$ H. Trevor-Roper, op. cit., s. 13. Tu szczegółowa analiza szkockiego mitu pochodzenia.

15 Hector Boethius, Scotorum Historia (1575 version), ed. D. F. Sutton, http://www. philological.bham.ac.uk/boece/fronteng.html (dostęp: 13.03.2020). 
że narracja (głównie zaś postać Artura) stworzona przez Geoffreya z Monmouth jest fikcją wymyśloną przez niego lub innych, rozpowszechnianą albo przez niekontrolowaną skłonność do fałszu, albo przez chęć przypodobania się Brytyjczykom ${ }^{16}$. Na uznanie tej krytyki trzeba było jednak poczekać, zwłaszcza że w drugiej połowie XII w. trojańskie pochodzenie mieszkańców Wysp Brytyjskich było popularyzowane w romansach: Brut Layamona i Le Roman de Troye francuskiego poety Benoît de Sainte-Maure'a.

Geoffrey z Monmouth należał do otoczenia angielskiego monarchy, co potwierdza dedykacja dla Roberta, hrabiego Gloucester, nieślubnego syna króla Henryka I (1100-1135). Do tego władcy nawiązywał Henryk II Plantagenet (1154-1189). Jego żonie, Eleonorze Akwitańskiej, zadedykował z kolei swoje dzieło Li roman de Brut (znane także jako Geste des Bretons, 1155) Robert Wace, opierający się na tradycji stworzonej przez Geoffreya z Monmouth. Tytulatura Henryka II odwoływała się do Normandii, Akwitanii oraz odziedziczonej po ojcu Andegawenii. Głównym celem jego ekspansji terytorialnej była Francja. Mityczny Brutus przed dopłynięciem na Wyspy Brytyjskie zawitał na ziemie francuskie, walczył z Galami i m.in. ufundował Tours. Relacja Geoffreya z Monmouth stanowiła więc argument na rzecz Henryka II w chęci „odzyskania” dawnych ziem brytyjskich. Dodatkowo w Bretanii funkcjonował „brytyjski” mit założycielski, a nie francuski ${ }^{17}$.

Kolejni władcy również odnosili się do kroniki Geoffrey z Monmouth, dowodząc konieczności podbicia Francji. Edward III (1327-1377), legitymizując ekspansję, wywołał konflikt, który przeistoczył się w wojnę stuletnią (1337-1453). Rywalizacja angielsko-francuska, odwołująca się do mitów pochodzenia obu państw, znalazła swoje odzwierciedlenie także

16 William of Newburgh, The history of William of Newburgh, https://sourcebooks. fordham.edu/basis/williamofnewburgh-one.asp\#preface (dostęp: 13.03.2020).

17 J. Rio, Mythes fondateurs de la Bretagne. Aux origines de la celtomanie, Rennes 2000; A.-Y. Bourgès, La cour ducale de Bretagne et la légende arthurienne au bas Moyen Âge. Prolégomènes à une édition critique des fragments du Livre des faits_d'Arthur, w: A travers les îles celtiques. Mélanges à la mémoire de Gwenaël Le Duc, éd. G. Buron, H. Bihan, B. Merdrignac, Rennes 2008, s. 79-119; J. Poucet, L'origine troyenne des peuples d'Occident au moyen âge et à la Renaissance. Un exemple de parenté imaginaire et d'idéologie politique, „Les Études Classiques" 2004, vol. 72, s. 82-85. 
w drukach okolicznościowych. Z jednej strony Anglicy przekonywali, że ich państwo ma o 1000 lat starszą od Francji historię ${ }^{18}$. Z drugiej zaś strony w połowie XV w. we francuskim pamflecie jego autor uznał, że dawni królowie Brytanii byli Trojanami, ale współcześni Anglicy są Sasami, którzy przywłaszczyli sobie chwalebną historię innego państwa. Ponadto Brutus, przed przybyciem do Albionu, toczył walki w Galii z tamtejszym rycerstwem, co tylko dowodzi, że społeczeństwo francuskie już wówczas było zhierarchizowane, a lud na Wyspach Brytyjskich - dziki ${ }^{19}$. Przeszłość okazywała się narzędziem, którym starano się dyskredytować wroga - zarówno władcę, jak i jego poddanych.

Mit założycielski był także wykorzystywany przez królów angielskich w polityce wewnętrznej. Dzięki trojańsko-arturiańskiej opowieści swoją władzę legitymizował Henryk II, zwłaszcza w sporze z Tomaszem Becketem (ok. 1118-1179), arcybiskupem Canterbury. Siedziba prymasa była symbolem przynależności do Rzymu. Monarcha kolebkę chrześcijaństwa angielskiego widział zaś w Glastonbury - miejscu, gdzie znajdował się rzekomy grób króla Artura ${ }^{20}$. Podkreślanie niezależności od Rzymu było widoczne w tzw. konstytucjach z Clarendon. Henryk II ograniczył w nich przywileje Kościoła w Anglii m.in. przez nałożenie podatku, ale też przez zakaz składania apelacji do Rzymu bez zgody monarchy. Prestiż Glastonbury podnosił Edward I (1272-1307), który wprost gloryfikował mit arturiański ${ }^{21}$.

Opowieść Geoffreya z Monmouth służyła także jako argument w jednoczeniu ziem Wysp Brytyjskich. Integrację zaczęto od Irlandii, gdzie kapelan Henryka II Gerald z Walii (ok. 1146-1223) uzasadniał prawa angielskich królów do rządzenia Irlandią właśnie treścią kroniki Geoffreya z Monmouth ${ }^{22}$. Z podporządkowaniem Walii było więcej problemów, ponieważ Walijczycy podkreślali odrębność swojego mitu założycielskie-

18 Liber monasterii de Hyda, ed. E. Edwards, London 1866, s. 5, cyt. za: A. Branny, Trojanie..., s. 7.

19 A. Branny, Trojanie..., s. 7.

20 Ibidem, s. 10-11.

21 Zob. R. Sh. Loomis, Edward I, Arthurian Entusiast, „Speculum” 1953, vol. 28, no. 1, s. 114-127.

22 A. Branny, Trojanie..., s. 12. 
go (arturiańskiego, a nie trojańskiego). Po kilkunastoletnich działaniach militarnych Edward I (1272-1307) proklamował swego syna, późniejszego króla Edwarda II (1307-1327), panem Walii, by zaakcentować swoją rosnącą pozycję w tej części Wysp Brytyjskich ${ }^{23}$. Opowieść Geoffreya z Monmouth była przez tego monarchę wykorzystywana także w celu zdominowania Szkocji. To właśnie mityczna opowieść o prapoczątkach mieszkańców Wysp Brytyjskich dawała mu argumenty, które przedstawiał jako dowody w swojej, podpisanej przez wielu baronów angielskich, korespondencji do papieża Bonifacego VIII ${ }^{24}$.

W społeczeństwie narastało oczekiwanie na pojawienie się władcy, który dokonałby ponownego zjednoczenia Anglii, Walii i Szkocji, jednocześnie wypełniając wizję Cadwaladra, że oto powróci dynastia brytyjska w postaci nowego Artura. Po bitwie pod Bosworth (22 sierpnia 1485 r.) decydującej w wojnie Dwóch Róż (1455-1485) - zakończyło się panowanie Plantagenetów w Anglii. W 1485 r. Walijczyk Henryk Tudor został nowym królem, a mityczna brytyjska historia stała się na nowo wiarygodna. Będąc dziedzicem po matce - krewnej Edwarda III ${ }^{25}$, monarcha szybko dostrzegł możliwość politycznego wykorzystania mitu o początkach państw, zatem Brutusa (Anglii) i Artura (Walii). W sferze wizualnej jako Henryk VII (1485-1509) używał herbu odnoszącego się nie tylko do Anglii i Francji, lecz także do Brutusa, Artura, Edwarda Wyznawcy i Wilhelma Zdobywcy. Z Walii maszerował triumfalnie ze sztandarem czerwonego smoka Cadwaladra - i ten symbol pozostał z nim przez cały okres jego panowania. Symbolika ta była używana przez kolejnych monarchów, m.in. królową Elżbietę.

Tudorowie mocno podkreślali swoje pochodzenie od najdawniejszego władcy na Wyspach - Brutusa; państwowy mit założycielski można nawet nazwać „mitem Tudorów” ${ }^{26}$. Nadworny historiograf, francuski augustianin Bernard André (1450-1522), późniejszy nauczyciel pierworodnego syna

23 A. Adolph, Brutus of Troy and the quest for the ancestry of the British, Barnsley 2015, s. 111 .

24 H. A. MacDougall, op. cit., s. 13-14.

$25 \mathrm{Na}$ zlecenie króla walijscy genealodzy „odnaleźli” jego powiązania w męskiej linii z Brutusem; zob. A. Adolph, op. cit., s. 112.

26 J. Carscallen, op. cit., s. 15. 
Henryka VII, opisując żywot monarchy (spisany między 1500 a 1502 r.), dowodził jego pochodzenia od Brutusa oraz gloryfikował jako tego, który wypełnił proroctwo, po którym nastąpi złoty wiek ${ }^{27}$. Coraz częściej też mamy do czynienia z zespoleniem dziedzictwa trojańsko-arturiańskiego. Najdobitniejszym odwołaniem się do legendy o królu Arturze było z kolei nazwanie pierworodnego syna monarchy właśnie Arturem, choć ten nie dożył przejęcia władzy.

Młodszy brat Artura Tudora - król Henryk VIII (1509-1547), wykorzystał mit trojański do innych celów. Dzięki kronice Geoffreya z Monmouth mógł legitymować się pochodzeniem od samego cesarza Konstantyna (który miał się urodzić w Brytanii). Anglicy mieli więc własną tradycję chrześcijańską - niezależną od papiestwa ${ }^{28}$. Monarcha mógł zatem religijnie i politycznie uniezależnić się od Rzymu.

Do popularyzacji mitu Brutusa w ostatniej ćwierci XV w. przyczynił się wydawca William Caxton (1415 lub 1422-1492). Pierwszą książką wydrukowaną w języku angielskim było tlumaczenie Recuyell of the Historyes of Troyes Raoula LeFèvre'a. Następnie Caxton opublikował liczące wiele wydań średniowieczne utwory The Chronicles of England (znane jako Chronicles of the Brut) oraz dzieło Ranulfa Higdena (ok. 1280-1364) Polychronicon ${ }^{29}$. We wszystkich tych pozycjach znajdowały się odniesienia do trojańskich początków państwa.

Opisy historii Anglii Johna Rousa (ok. 1411/1420-1492) i Williama Worcestera (1415-ok. 1482) również rozpoczynały się od Brutusa. Mimo że dzieło Geoffreya z Monmouth wzbudzało wątpliwości już w XII w., trudno było odrzucić postać wyimaginowanego fundatora i kolejnych władców bez wymyślenia innej opowieści ${ }^{30}$. Humphrey (Onufry) Lancaster, ksią-

27 A. Branny, Trojanie..., s. 14.

28 O wykorzystaniu przeszłości (nie tylko tej dotyczącej Brutusa) w debacie między katolikami a protestantami zob. F. Heal, Appropriating history: catholic and protestant polemics and the national past, w: The uses of history in early modern England, ed. P. Kewes, San Marino 2006, s. 105-128, odwołania do Geoffreya z Monmouth, s. 116-117.

29 O popularności Polychronicon w: D. R. Woolf, Reading history in early modern England, Cambridge 2000, s. 13; H. A. MacDougall, op. cit., s. 15.

30 D. Woolf, From hystories to the historical: five transitions in thinking about the past, 1500-1700, w: The uses of history..., s. 64. 
żę Gloucester (1390-1447), był według Thomasa D. Kendricka pierwszym angielskim władcą, który sceptycznie podchodził do trojańskiego rodowodu królów angielskich ${ }^{31}$. Wywodzący się z jego otoczenia John Capgrave (1393-1464) także był podejrzliwy wobec przekazu Geoffreya z Mon mouth. Jeszcze więcej krytycyzmu wobec jego wiarygodności przejawiał włoski uczony Flavio Biondo (1392-1463). W wydanej w 1483 r. pracy Historiarum ab inclinatione Romanorum imperii decades zawierającej historię Anglii całkowicie pominął on dzieło Geoffreya z Monmouth. W swoich notatkach o Historia rerum Britannia napisał, że nigdy nie czytał książki tak pełnej kłamstw oraz głupot, które przewyższały sny chorych ${ }^{32}$. Odrzucenie dorobku angielskiego kronikarza było więc spowodowane surową jego oceną.

Krytyka wobec mitów pochodzenia osób z zagranicy często wywoływała odwrotny do zamierzonego skutek, rozbudzając patriotyzm rozumiany jako obrona tradycji, w tym opowieści fundacyjnej. Wkrótce jednak po Biondzie szkocki uczony John Major (1469-1550) po latach spędzonych w Paryżu wrócił w 1521 r. do swojej ojczyzny i opublikował Historia Majoris Britanniae. Wszystkie tak ważne dla narodowej historii symbole zostały w dziele zdyskredytowane, w tym za absurdalne uznane opowieści zarówno o Brutusie, jak i o Scocie. Uczony wierzył jednak w profetyczne słowa o nadejściu nowego Artura ${ }^{33}$. Podobnie szwagier Tomasza More’a (1478-1535), John Rastel, potraktował opowieść o Brutusie jako „piękną bajkę”34.

Przed pracą Majora przestrzegał Gavin Douglas (1474-1522), biskup Dunkeld, Polydore'a Vergila (ok. 1470-1555). To jedna z kluczowych postaci w dyskusji o trojańskich początkach na Wyspach Brytyjskich. Włoski uczony przybył do Anglii na początku XVI w., stając się wkrótce historiografem króla Henryka VII, który zlecił mu opisanie historii Anglii ${ }^{35}$. Ver-

31 T. D. Kendrick, op. cit., s. 34.

32 Cyt. za: F. Montorsi, Faut-il croire à Geoffroy de Monmouth? Notes sur la réception de l'Historia regum Britannie au XVIe siècle (1508-1579), „Tirant” 2019, no 22, s. 266.

33 J. Major, Historia Majoris Britanniae, tam Angliae, quam Scotiae, Edinburgh 1740, s. $35-37$.

34 Cyt. za: H. A. MacDougall, op. cit., s. 20.

35 E. A. Mierzwa, Historia historiografii, t. 2: Renesans-Oświecenie, Warszawa 2007, s. 184. 
gil był sceptyczny wobec pochodzenia Brutusa, ponieważ nie pojawiał się on w antycznych źródłach (pismach m.in. Juliusza Cezara, Tacyta, Tytusa Liwiusza). Dzieło Vergila zatytułowane Anglica Historia ukazało się drukiem w 1534 r., ale nie na Wyspach, tylko w Bazylei. Zresztą pierwsze siedem jego wydań z XVI w. opublikowano za granicą ${ }^{36}$. W Vergila wersji dziejów państwa ani Brutus, ani Artur nie byli postaciami rzeczywistymi. Jak podkreśla Thomas D. Kendrick, włoski uczony nie był stłamszony tradycją Brutusa, króla Artura i wypełnienia jego proroctwa przez panującą wówczas dynastię Tudorów, nie musiał więc naginać kroniki do potrzeb narodowych ${ }^{37}$. Pracę Vergila starano się dyskredytować, zwłaszcza że rok jej wydania - 1534 - okazał się czasem zerwania Henryka VIII z Rzymem. Przez Anglików włoski uczony został uznany za papistę, a oni sami podjęli rękawicę w walce o uznanie historyczności swoich protoplastów. Debata między zwolennikami a przeciwnikami trojańsko-arturiańskich origines stała się w rzeczywistości sporem przede wszystkim polityków z władzami Kościołów.

Największą pasją w odpowiedzi Vergilowi wykazał się założyciel Towarzystwa Antykwariuszy John Leland (1506-1552), uważany za najważniejszy autorytet w kwestii angielskich starożytności. Przed publikacją pracy Assertio inclytissimi Arturri Regis Britanniae (1544) wskazywał na Vergila jako tego, którego z włoskich historyków warto czytać ${ }^{38}$. Antykwariusz miał jednak inny cel - chciał pomóc Henrykowi VIII w antypapieskiej propagandzie, gloryfikując króla kończącego z władzą Rzymu na Wyspach.

Z krytyką nie wobec pracy Vergila, ale wobec wszystkich Rzymian tych z przeszłości i tych współczesnych - wystąpił Walijczyk Arthur Kelton (zm. 1499/1500) w dziele dedykowanym Edwardowi VI pt. A Chronicle with a Genealogie declaring that the Brittons and Welshmen are linealiye dyscended from Brute (1547). Kultywując przekaz Geoffreya z Monmouth, uznał, że jeśli znajdzie coś dyskredytującego w historii starożytnego Rzymu lub rzymskiego Kościoła, z radosną satysfakcją to opublikuje. Wierzył, że Włosi mają tak wstydliwą przeszłość, że celowo tłamszą historię Wysp

\footnotetext{
36 A. F. Grabski, Dzieje historiografi, wprow. R. Stobiecki, Poznań 2011, s. 195.

37 T. D. Kendrick, op. cit., s. 83.

38 Ibidem, s. 52.
} 
Brytyjskich. Podkreślał, że Brytowie mają starszą proweniencję od Rzymian, którzy niszczyli praworządność, pochwalali tyranię, niewolnictwo, czego nie doświadczyło społeczeństwo pod panowaniem Brutusa ${ }^{39}$.

Złośliwości wobec Vergila wystrzegał się sir John Prise (1501/1502-1555) w Historiae Britannicae Defensio (1553, wyd. 1573). Ślepo wierzył on w wizję Geoffreya z Monmouth, odpowiadając na argumenty Włocha prozaicznie: Rzymianie opisywali dzieje dla samych siebie, dlatego nie wspominali o Brutusie. Prise skupił się na nazwie „Britannia”, która według niego musiała pochodzić od Brutusa. Przyznawał, że państwo powinno nazywać się „Brutannią”, ale odnalazł w języku Rzymian podobną nieścisłość. Od słowa consulo wzięło się consilium, choć należałoby mówić consulium. Ta zmiana „u” na „i” została zatem także zastosowana w nazwie państwa Brytów. Kolejne dowody Prise’a są podobne, głównie odnoszą się do nazewnictwa postaci i miejsc, które według niego Vergil podawał błędnie ${ }^{40}$.

Andrzej Branny słusznie podkreśla, że dzieła Lelanda, Keltona czy Prise’a to już nie „średniowieczna kronika rodowodowa, lecz próba interpretacji przeszłości w kategoriach procesu dziejowego. [...] Opowieści Geoffreya nabierają tym samym charakteru historiozofii, której sens stanowi spełnianie się wolności” ${ }^{41}$.

Krytykę personalną wobec włoskiego uczonego kontynuował pierwszy angielski historyk Kościoła, John Bale (1495-1563), uznając, że „Vergil jest płatnym szpiegiem papieskim, któremu postawiono zadanie zdemoralizowania narodu angielskiego i odarcia go z jego najczcigodniejszych tradycji” “2. W okresie wciąż napiętych relacji papiestwa z Kościołem anglikańskim Bale dodał początkom swego państwa podstawy biblijne, prezentując antycznych przodków jako pochodzących od Jafeta. Razem z Henrykiem VIII Brutus stał się symbolem niezależności od papiestwa.

W tym samym 1548 r. George Lily (zm. 1559) uznał jednak, że opowieść Geoffreya z Monmouth ma znamiona sentymentalnego patriotyzmu, historia ta zaś jest nonsensem i nie może być przytaczana w opisie dziejów

\footnotetext{
39 Ibidem, s. 86-77.

40 Ibidem, s. 91-92.

41 A. Branny, Trojanie..., s. 16.

42 Ibidem, s. 15.
} 
państwa. Rok później kronikarz Thomas Lanquet (1521-1545) stwierdzał, że dzieło średniowiecznego pisarza było pełne błędów ${ }^{43}$. Tego typu przykłady większego krytycyzmu wobec średniowiecznej tradycji były jednak pojedyncze.

Za panowania Elżbiety I (1558-1603) mit trojańsko-arturiański był jedną z dominujących idei politycznych. Prezentowanie Elżbiety jako władczyni rozpoczynającej arturiański złoty wiek jest widoczne zwłaszcza w Królowej wieszczek Edmunda Spensera (ok. 1552-1599). Głównym bohaterem utworu jest król Artur. Pełnił on inną funkcję niż Brutus czy Cadwaladr - był postacią jednoczącą społeczeństwo, która kształtowała ducha wieku elżbietańskiego ${ }^{44}$. Co ciekawe, Spenser nie wierzył w mityczne prapoczątki państwa ${ }^{45}$, ale to nie przeszkodziło mu w wykorzystaniu legendy. W eposie Artur poznaje historię Brutusa - prawnuka Eneasza ${ }^{46}$. Brutus wspomina całe swoje życie - od zabicia ojca, przez podróż do Grecji, następnie z wyzwolonymi Trojańczykami do Brytanii, po pokonanie olbrzymów i zasiedlenie wyspy. Od syna Brutusa Locrinusa wywodzili się kolejni władcy, włącznie z Learem i Cymbelinem, którego przodkom Józef z Arymatei dostarczył do Brytanii Święty Graal. Opowieść Spensera pokrywa się ze średniowieczną wizją początków państwa, ale zawiera w sobie więcej motywów - przede wszystkim chrześcijańskich, jak również zaczerpniętych z mitologii greckiej. Jedną z bohaterek Królowej wieszczek jest Britomartis córka Zeusa i nimfy Karme, towarzyszka Artemidy ${ }^{47}$, która chcąc zachować dziewictwo, uciekając przed Minosem, rzuciła się do morza. Upadek przeżyła, a schronienie znalazła w świętym gaju bogini łowów. W dziele Spensera Britomartis jest alegorią Elżbiety I, zwanej Królową-Dziewicą. Podobnie

${ }^{43}$ T. D. Kendrick, op. cit., s. 41-42.

44 A. Lupack, Introduction, w: Modern Arthurian literature. An anthology of English and American Arthuriana from the Renaissance to the present, ed. A. Lupack, New York-London 1992, s. 3; A. E. Parsons, The Trojan legend in England. Some instances of its application to the politics of the times, "The Modern Language Review” 1929, vol. 24, no. 3, s. 256.

${ }^{45}$ T. D. Kendrick, op. cit., s. 128.

46 Omówienie dzieła Spensera, także w kontekście mitologii grecko-rzymskiej, w: J. Carscallen, op. cit., s. 29-37.

${ }_{47}$ A. Adolph, op. cit., s. 114. 
w wystawionej przed monarchinią w 1588 r. tragedii The Misfortunes of Arthur Thomas Hughes (najpewniej 1571-1623) chwalił Elżbietę ukazaną jako Dziewicę, pochodzącą od Brutusa, będącą „pozostałością” po Priamie nadzieją na odrodzenie się Troi ${ }^{48}$.

Sztuki sceniczne w dobie panowania Elżbiety I kwitły. Wśród tych nawiązujących do Brutusa można wymienić: The Tragedy of Dordubuc, Locrine, Brute Greenshield czy Conquest of Brute. W 1598 r. inscenizowano The Conquest of Brute with the First Founding of Bath Henry'ego Chettle'a i Johna Daya w Rose Theatre. W konkurencyjnym Globe Theatre wystawiano Króla Leara (ok. 1603/1607) i Cymbelina (1611) Williama Shakespeare’a (1564-1616) - opowiadające o mitycznych władcach rządzących po Brutusie, choć on sam nie pojawił się na kartach dramatów. Trojańskie początki państwa zostały przywołane w Henryku V (ok. 1599) oraz Troilusie i Kresydzie (ok. 1602). W największym stopniu Shakespeare odwoływał się do wizji Geoffreya z Monmouth w The Lamentable Tragedy of Locrine z 1595 r. Dramat ten opowiada o synu Brutusa - Locrinusie, ale rozpoczyna się opisem ostatnich dni Brutusa w Trinovantum i podziałem ziem między jego synów.

Do mitycznych początków państwa krytycznie odniósł się w 1582 r. szkocki uczony George Buchanan (1506-1582). W Historii szkockiej zwracał uwagę, że nawet współcześni uczeni, wabieni ambicją, starają się wywyższyć prapoczątki państwa. Trudno jednak według Buchanana traktować je poważnie, raczej narażają one społeczeństwo na śmieszność. Pisarz najpierw rozprawia się z mitem o Brutusie, by za chwilę zganić swoich rodaków za chęć wymyślenia bardziej szlachetnego od Brytów pochodzenia Szkotów. Obydwie opowieści ukazał jako niedorzeczne bajki. W przypadku Brutusa drwiąco zastanawiał się chociażby nad tym, jak to się stało, że po kilkunastu latach rządów na bezludnej dotychczas wyspie (na której mieszkali tylko

48 „That virtuous Virgo, borne for Brtyaines blisse; / That peerlesse braunch of Brute; that sweete remaine / Of Priam's state; that hope of springing Troy"; Th. Hughes, Misfortunes of Arthur, London 1828, s. 77. 
olbrzymi) jego synowie sprawowali rządy nad poddanymi zamieszkałymi w miastach ${ }^{49}$.

Krytyczny, choć w nieironiczny sposób, wobec tradycji był również „angielski Pauzaniasz” William Camden (1551-1623) w chorograficznej pracy Brittannia (1586). Pracując nad tym dziełem, wzorował się na wspomnianym Biondzie i jego Italii ${ }^{50}$. Camden zwrócił uwagę na konwencję eponimów w dziełach średniowiecznych: Scota i Szkocja, Francjon i Francja, Saxnot i Sasi itp. ${ }^{51}$, stąd łatwość w wytłumaczeniu nazwy „Brytania”. Ta zaś miała w rzeczywistości składać się ze słów łacińskich „Brith” (Brytowie) i „-tania”, jak „Akwi-tania” czy „Luzy-tania”, i pochodzić z czasów rzymskich $^{52}$. Do 1600 r. dzieło to miało cztery wydania, a w 1607 r. ukazała się angielska wersja książki. Według Daniela R. Woolfa żaden angielski pisarz nie zrobił tyle co Camden, by osłabić przekaz Geoffreya z Monmouth - Britannia była najbardziej wpływową książką o antycznych pozostałościach ${ }^{53}$. Od tej pory popularność Brutusa spadała, choć jego imię trwało w pamięci zbiorowej. Dodatkowo Camden udowadniał, że również mit szkocki jest nieprawdziwy.

Nie wszyscy jednak zgadzali się na krytykę państwowych fundamentów. W wydanej w tym samym roku pracy Albion's England William Warner (1558?-1609) opisywał tak zamierzchłe dzieje państwa, że historia o Trojańczykach w Brytanii pojawiła się dopiero w trzeciej księdze jego dzieła, na dodatek była traktowana poważnie ${ }^{54}$.

W dobie wczesnonowożytnej mit Brutusa był wykorzystywany przede wszystkim przez Tudorów, ale i Stuartowie z pasją go kultywowali.

49 G. Buchanan, Rerum Scoticarum Historia, 1582, http://www.philological.bham. ac.uk/scothist/2eng.html (dostęp: 13.03.2020).

50 A. F. Grabski, op. cit., s. 197.

51 W. Camden, Britannia, sive florentissimorum regnorum Angliae, Scotiae, Hiberniae et insularum adiacentium..., Frankfurt 1590, s. 6-7.

52 Ibidem, s. 28.

53 D. R. Woolf, The idea of history in early Stuart England. Erudition, ideology, and "The Light of Truth" from the accession of James I to the Civil War, Toronto-Buffalo-London 1990, s. 21.

54 W. Warner, Albions England..., London 1586, https:/quod.lib.umich.edu/e/eebo/ A14779.0001.001/1:6?rgn=div1; view=fulltext (dostęp: 13.03.2020). 
W 1603 r. tron angielski objął dotychczasowy władca Szkocji Jakub Stuart, którego prababcia była córką Henryka VII. Anglicy znaleźli się poniekąd pod obcym władcą, który pragnął połączyć dwa królestwa, ale przeciwników miał właściwie po obu stronach granicy. Gdy Jakub I (1603-1625) został władcą dwóch państw, opowieść trojańska znajdowała aprobatę, bo wspólne pochodzenie obu krajów umocniło unię personalną z 1603 r. Także tytulatura nowego monarchy, pojawienie się w niej „Szkocji”, pogłębiła wspólną, angielsko-szkocką dumę. Na formalne zjednoczenie Królestwa Anglii i Królestwa Szkocji musiano co prawda poczekać ponad 100 lat, jednak wizje wspierające królewską propagandę, wykorzystujące opowieść trojańską, prezentowano już wówczas nader chętnie. W Triumphs of Reunited Britannia Antony'ego Mundaya z 1605 r. bohaterem pierwszej części jest Brutus i jego synowie, w dalszej zaś „drugim Brutusem” staje się król Jakub I, ten, który połączył podzielone przez założyciela Brytanii państwo ${ }^{55}$. W tym czasie w Londynie na Fleet Street zbudowano łuk triumfalny z alegorycznymi figurami Anglii, Szkocji, Francji i Irlandii i przypominano: „By Brute divided, but by you alone / All are again united and made one" 56 . Dzieło zjednoczenia dwóch narodów przez nowego Brutusa zostało przez Edwarda Ayscu (1550-1616/1617) zaprezentowane jako akt Boga mający na celu wzmocnienie angielskiego protestantyzmu przeciwko papieskiemu antychrystowi ${ }^{57}$.

W czasie panowania Stuartów propagowanie mitu o trojańskich początkach jest widoczne w wielu utworach. Odżył też atak na uczonych kwestionujących średniowieczny przekaz Geoffreya z Monmouth. Wydawca Edmund Howes (najpewniej 1607-1631) dodał rozdział zatytułowany A Briefe Proofe of Brute do wydanego w 1615 i 1631 r. dzieła kultywującego postać Brutusa jako fundatora Brytanii Johna Stowa (1524/1525-1605). Howes uznał, że Polydor Vergil godził w autorytet oraz prawomocność

55 A. Mundy, The triumphes of re-vnited Britania, London 1605, https://mapoflondon.uvic.ca/TRIU2.htm (dostęp: 13.03.2020).

56 Th. Dekker et al., The whole royal and magnificent entertainment of king James through the city of London, 15 March 1604, with the Arches of Triumph, ed. R. M. Smuts, w: Th. Middleton, The collected works, ed. G. Taylor, J. Lavagnino, New York 2007, s. 263. Tam też ilustracja łuku triumfalnego (ibidem, s. 262).

57 D. R. Woolf, The idea of history in early Stuart England..., s. 59. 
władzy pochodzącej od przodków, co jest nie do przyjęcia ${ }^{58}$. Wielu uczonych z Towarzystwa Miłośników Starożytności Brytyjskich (Society of Antiquaries) również traktowało wizję Geoffreya z Monmouth jako prawdziwą. Wśród nich znaleźli się m.in. Arthur Agard (zm. 1615), Joseph Holland czy James Ley ${ }^{59}$.

Niektórzy historiografowie byli rozdarci w kwestii prawdziwości fantastycznych władców. John Speed w The History of Great Britaine (1614) twierdził, że w najdawniejszych czasach na ziemiach brytyjskich było więcej Rzymian niż Trojan. Według niego należało odrzucić tradycję (i realność) Brutusa, traktując go jako bohatera raczej literackiego ${ }^{60}$, aczkolwiek Artura uznawał za postać historyczną. Co ciekawe, Speed dedykował swoje dzieło Jakubowi I - jako temu, który „zjednoczył brytyjskie imperium”"

Podobnego zdania na temat mitycznego fundatora Brytanii był John Selden (1584-1654). We wstępie do Analecton Anglobritannicon (1615) uznał dzieje Brutusa za piękną opowieść dla artystów i poetów ${ }^{62}$. O krok dalej poszedł sir Walter Raleigh, który pominął milczeniem Brutusa w History of the World (1614). Samuel Daniel zaś w pracy z 1612 r. zadawał retoryczne pytanie, że skoro Brytowie nie byli wzmiankowani w dziełach antycznych, to jak mogła przetrwać ich historia. Nie wierzył, że Brytanią mogli rządzić królowie, podczas gdy państwa Europy Zachodniej dopiero się tworzyły. Podobnie wypowiadał się Digory Whear w swoim przewodniku dotyczącym literatury historycznej - zalecał raczej lekturę Camdena czy Seldena aniżeli Geoffreya ${ }^{63}$.

58 T. D. Kendrick, op. cit., s. 100.

59 Ibidem, s. 101.

60 J. Speed, The history of Great Britaine under the conquests of Ye Romans, Saxons, Danes and Normans..., London 1614, s. 164.

61 „To the most high, and most potent monarch, Iames, of Great Britaine, France, and Ireland King, the most constant and most learned defender of the faith, inlarger and vniter of the British empire, restorer of the British name, establisher of perpetvall peace, in Church, and Commonwealth, president of al pricely verves and noble arts", ibidem, dedykacja.

62 J. Selden, Analecton Anglobritannicon libri duo..., Frankfurt 1615, praefatio, s.p.

63 T. D. Kendrick, op. cit., s. 110. 
W XVII w. akceptacja lub odrzucenie trojańskiej opowieści miały silny związek z walką o władzę między królem a parlamentem: im władza monarsza była silniejsza, tym mocniej odżywało zainteresowanie chwalebnymi początkami ${ }^{64}$. Rozgorzała debata nad źródłem praw: czy pochodzą one od Boga, czy od Brutusa. Sędzia sir Edward Coke (1552-1634), przeciwnik teorii o boskim prawie królewskim, w przedmowie do Reports pisat, że Brutus, chcąc zapewnić sobie spokojne rządy, stworzył pierwszą księgę praw (w języku greckim), które pochodziły z Troi ${ }^{65}$. Brutus nie był zatem twórcą praw, a ich dawcą. Zwolennicy zwiększenia przywilejów parlamentu, co oczywiste, odrzucili tradycję mitu trojańsko-arturiańskiego, który nie pokrywał się z ich ideałami i interesami politycznymi. Monarchiści byli zaś entuzjastami Geoffreyowskiej wizji przeszłości kraju. Argumentowali, że Brutus ufundował królestwo, jego następcy doskonale nim rządzili i nie dostrzegali potrzeby zmiany ustroju czy podzielenia się władzą z częścią poddanych.

W czasach restauracji zwolennicy dynastii powrócili do propagowania jedynowładztwa - wiara w mit założycielski była „ideową reprezentacją obozu rojalistycznego i absolutystycznych dążeń Stuartów" ${ }^{66}$. Już po wstąpieniu na tron Karola II Stuarta w 1660 r. Percy Enderby w pracy Cambria Triumphans (1661) przypominał o walijskich przodkach Stuartów. Daniel Langhorne w Introduction to the History of England (1676) uznawał, że wizja Geoffreya z Monmouth nie może zostać utrzymana, ale źle byłoby odrzucać całą narrację o Brutusie ${ }^{67}$. Trudno ocenić, czy pogląd ten wyrażał szacunek dla tradycji, czy raczej dostrzeganie możliwości wykorzystywania mitu o trojańskich przodkach.

W czasie rządów Jakuba II (1685-1688) powróciła kwestia źródeł prawa. Wraz z rozwojem parlamentaryzmu, propagowaniem idei wyższości prerogatyw parlamentu nad prawem boskim entuzjazm wobec mitycznych dziejów malał ${ }^{68}$. Krótkie ożywienie zainteresowania nimi było związane

64 R. F. Brinkley, Arthurian legend in the seventeenth century, London 1967, s. 26.

65 D. Ch. Smith, Sir Edward Coke and the reformation of the laws. Religion, politics and jurisprudence, 1578-1616, Cambridge 2014, s. 125.

66 A. Branny, Trojanie..., s. 16.

${ }_{67}$ T. D. Kendrick, op. cit., s. 101.

68 R. F. Brinkley, op. cit., s. 87. 
z odwoływaniem się do legendy (choć już tylko arturiańskiej) przez Wilhelma Orańskiego (1689-1702) ${ }^{69}$.

Rozdarcie między uznaniem prawdziwości mitu a stopniową ewolucją w kierunku jego odrzucenia znajduje również odzwierciedlenie w literaturze pięknej XVII w. Aluzje do Brutusa i jego następców pojawiły się w Troia Britannica Heywooda (1609), zwłaszcza zaś w Poly-Olbion (1612, pełna wersja 1622) Michaela Draytona. Poemat ten zawiera aktualny kontekst trojańskiej opowieści: od odkrycia Brytanii przez Brutusa, przez pojawienie się Tudorów, po gloryfikację Stuartów i wielkość ich państwa.

Zupełnie inaczej na problem historii ojczyzny spojrzał Matthias Prideaux (1622-1646?). W swoim kompendium historycznym (1648), obejmującym dzieje od czasów biblijnych, opisał również dzieje Brytanii. Po każdym podrozdziale (dla nas interesujaccy jest ten zatytułowany Trojanie) autor zadaje pytania retoryczne, które skłaniają do krytycznych odpowiedzi ${ }^{70}$. W dziełach historycznych publikowanych pod koniec XVII w. postać Brutusa coraz częściej przemilczano lub przyznawano, że powinna być opuszczana $^{71}$. W wydanej w 1670 r. History of England John Milton (1608-1674) uznał, że opowieść o trojańskim bohaterze wydaje się oparta na faktach, ale winni z niej korzystać raczej poeci (na dodatek rozważnie) ${ }^{72}$. W 1678 r. w Duke Theatre wystawiono dramat popularyzujący mityczne początki - Brutus of Alba: or the Enchanted Lovers Nahuma Tate'a ${ }^{73}$. Należy

69 Ibidem, s. 88.

70 M. Prideaux, Easy nad compendious introduction for reading all sorts of histories, Oxford 1672, s. 272. Było to piąte wydanie dzieła.

71 T. D. Kendrick, op. cit., s. 111.

72 „Nevertheless there being others besides the first suppos'd Author, men not unread, nor unlerned in Antiquitie, who admitt that for approved story, which the former explode for fiction, and seeing that oft-times relations heertofore accounted fabulous have bin after found to contain in them many footsteps, and reliques of somthing true, as what we read in Poets of the Flood, and Giants little beleev'd, till undoubted witnesses taught us, that all was not fain'd; I have therfore determin'd to bestow the telling over ev'n of these reputed Tales; be it for nothing else but in favour of our English Poets, and Rhetoricians, who by thir Art will know, how to use them judiciously"; J. Milton, The history of Britain, London 1670, s. 3, https://quod.lib.umich.edu/e/eebo/A50902.0001.001/1:3? rgn=div1;view=fulltext (dostęp: 13.03.2020).

73 A. Adolph, op. cit., s. 119. 
jednak podkreślić, że w kulturze popularnej częściej wówczas popularyzowano postać króla Artura niż Brutusa ${ }^{74}$.

Historiografia czasów oświecenia inaczej podchodziła do problemu mitu założycielskiego. Andrzej Branny słusznie dostrzegł zmianę ustroju, większy niż we wcześniejszych stuleciach udział w rządzeniu parlamentu, który nie potrzebował „legitymacji w postaci mitu o królach-budowniczych państw"75. Mimo to postać Brutusa pojawiała się w dziełach historiograficznych, kompendiach wiedzy czy wreszcie literaturze pięknej, chociażby w utworach Jakuba Hildebranda Brutus the Trojan, Founder of the British Empire: an Epic Poem (1735) czy Aleksandra Pope'a (1688-1744), który napisał poemat Brutus (niestety zachowały się tylko początkowe fragmenty).

Jedną z przyczyn popularności średniowiecznej opowieści fundacyjnej była idea posiadania wspólnej historii mieszkańców Wysp Brytyjskich na dodatek bardziej chwalebnej niż barbarzyńscy Sasi. Mit o trojańskim pochodzeniu integrował tamtejsze społeczeństwo. Proweniencja spod Troi zapewniała prestiż, co było propagandowo wykorzystywane przez królów, głównie w okresie dążenia do wzmocnienia monarchii przez Stuartów. Podstawą mitu pochodzenia była relacja Geoffreya z Monmouth, który opowieść o przybyciu Brutusa na ziemie brytyjskie i fundację przyszłej stolicy uczynił mitem założycielskim Anglii. Praca tego średniowiecznego pisarza odniosła niebywały sukces wydawniczy, czego dowodzą przykłady wykorzystania mitycznych początków „brytyjskich” przez licznych historyków i tłumaczenie dzieła na inne języki. W kręgu łacińskojęzycznym była to najpoczytniejsza świecka książka ${ }^{76}$. Na Wyspach Brytyjskich zaś kronikarz przez lata był autorem najważniejszej pracy opisującej rodzime prapocząt-

74 M. J. C. Reid, The Arthurian legend. Comparison of treatment in modern and mediaeval literature. A study in the literary value of myth and legend, Edinburgh-London 1938 (reprint 1960); R. F. Brinkley, op. cit., zwłaszcza s. 89-122.

75 A. Branny, Trojanie..., s. 18.

76 F. Montorsi, op. cit., s. 261; por. W. Lipoński, Dzieje kultury brytyjskiej, Warszawa 2003 , s. 104-105. 
ki, do której przez stulecia nawiązywano w innych dziełach kronikarskich, $\mathrm{w}$ poezji, w wypowiedziach politycznych. Elementy zaczerpnięte z pracy Geoffreya z Monmouth były przedmiotem debaty między średniowiecznymi i nowożytnymi uczonymi. Erudyci wierzący w prawdziwość tej opowieści wciąż podnosili jej wagę jako przedmiotu do studiowania historii państwowej, mogącej pomóc w argumentacji w sporach politycznych ${ }^{77}$.

Przez stulecia, mimo że coraz wyraźniej i głośniej krytykowany, mit był wykorzystywany w rozgrywkach politycznych: czy to wewnątrzpaństwowych, czy to w polityce zewnętrznej, zarówno w kwestiach terytorialnych, jak i religijnych. Ponadto pełnił funkcję propagandową w poezji i dramacie, można powiedzieć, narodowym, gdy gloryfikowano władzę monarszą, wywodzącą się od Brutusa. Opowieść o nim i o trojańskim pochodzeniu przetrwała, bo Geoffrey z Moumouth udowodnił, że Brytania nie była izolowana od Europy - konotacje z Troją zapewniały jej bardzo duże powiązanie z europejską cywilizacją ${ }^{78}$.

W dobie renesansu Anglicy w kwestii przeszłości swego państwa opierali się bezpośrednio lub pośrednio na Geoffreyu ${ }^{79}$. Coraz wyraźniejszy krytycyzm doprowadził do większego sceptycyzmu i odrzucenia mitycznych bohaterów, jednak do końca XVII w. nie zniknęli oni na dobre z kart dzieł. Brutus i kolejni mityczni władcy byli propagandowo wykorzystywani przez królów z dynastii Tudorów i Stuartów, zręcznie posługujących się symbolami z zamierzchłej przeszłości i osiągających dzięki temu kolejne cele swej polityki. Przykładem mogą być działania sprzed ustanowienia Kościoła anglikańskiego, które nie miały na celu ewangelizacji państwa, tylko kontrolowanie wpływów Rzymu na Wyspach ${ }^{80}$. Odwoływanie się do trojańskiego pochodzenia kraju legitymizowało władzę, najpierw w odniesieniu do konkretnego monarchy, następnie w sporach dotyczących prerogatyw króla i uprawnień parlamentu. W przeciwieństwie do Francji, która w XVII w. w dużym stopniu zweryfikowała swój mit początku, w Wielkiej Brytanii

T. D. Kendrick, op. cit., s. 7.

${ }^{78} \mathrm{~J}$. Kenyon, History men. The historical profession in England since the Renaissance, London 1993, s. 3.

79 Ibidem, s. 2.

${ }^{80}$ M.-B. Bruguière, De Brutus à Britannia: Troyens, Romains et saints dans le Moyen-Age britannique, w: Moyen Age chrétien et Antiquité, éd. G. Guyon, Paris 1999, s. 90. 
częściowo go zachowano, gdzieniegdzie - zwłaszcza w kulturze popularnej końca XVIII i w XIX w. - wręcz go wzmacniano ${ }^{81}$.

$\mathrm{Z}$ powodu popularności, częstego wykorzystania mitu trojańskiego przez kolejnych monarchów opozycyjnym przywódcom politycznym i historykom trudno było przekonać społeczeństwo do zmiany opinii w kwestii państwowego mitu założycielskiego. Mimo wszystko rozgorzała dyskusja na temat prawdziwości Brutusa, którego uznawano za zbyt odległego w czasie, by jego istnienie było w pełni potwierdzone, następnie zaś wokół króla Artura, który według XVI-wiecznych historyków należał już do epoki, w której rozróżnienie między prawdą a legendą powinno być możliwe ${ }^{82}$.

Mit o trojańskich początkach mieszkańców Wysp Brytyjskich był elementem narodowej legendy, zaadaptowanej na wzór innych państw zachodnich. Jak podkreślił A. E. Parsons, Brutus i jego potomkowie zostali zaakceptowani przez historyków jako założyciele i twórcy Brytanii, ale to Artur i jego świta trafili do serc i wyobraźni społecznej ${ }^{83}$. Co warte zaakcentowania, poszczególne rody szlacheckie, szukając swych początków, unikały odwoływania się do legendarnych władców - Brutusa czy Artura. W XVII w. najpopularniejszym okresem, w którym doszukiwano się przodków, był okres anglo-normański, zwłaszcza 1066 r., czyli bitwa pod Hastings $^{84}$.

81 Ibidem, s. 91.

82 R. F. Brinkley, op. cit., s. VII-VIII; por. L. A. Finke, M. B. Shichtman, King Arthur and the myth of history, Gainesville [et al.] 2004.

83 A. E. Parsons, op. cit., s. 253.

84 D. Woolf, The social circulation of the past. English historical culture 1500-1730, Oxford 2003, s. 122-123. 
